\title{
An Intubated Patient with a Blue Tongue: Don't Forget Benzocaine-Induced Methemoglobinemia
}

\author{
Bryan A Kerner ${ }^{1 *}$, Jin Hong Min ${ }^{2}$ and Frederick Hasty ${ }^{3}$ \\ ${ }^{1}$ Department of Anesthesiology, Mount Sinai Medical Center of Florida, Florida \\ ${ }^{2}$ Nova Southeastern University K.C. Patel College of Osteopathic Medicine, Florida \\ ${ }^{3}$ Miami Beach Anesthesiology Associates, Inc, Florida
}

*Corresponding author: Bryan Kerner, Department of Anesthesiology, Mount Sinai Medical Center of Florida, 4300 Alton Rd,

Miami Beach, FL 33140, Florida

\begin{tabular}{|c|c|}
\hline ARTICLE INFO & ABSTRACT \\
\hline Received: 幽 October 09, 2019 & Citation: Bryan A Kerner, Jin Hong Min, Frederick Hasty. An Intubated Patient with \\
\hline Published: 慧October 16, 2019 & $\begin{array}{l}\text { Blue Tongue: Don't Forget Benzocaine-Induced Methemoglobinemia. Biomed J Sci \& } \\
\text { Tech Res 22(1)-2019. BJSTR. MS.ID.003694. }\end{array}$ \\
\hline
\end{tabular}

\section{Introduction}

Benzocaine-induced methemoglobinemia is a rare but lifethreatening condition. An 83-year-old female with history of congestive heart failure underwent a transcatheter aortic valve implantation. Benzocaine was applied orally prior in preparation for a trans-esophageal echocardiogram. Shortly after the patient's 02 saturation dropped from $97 \%$ to a persistent $85 \%$ despite giving $100 \%$ oxygen. Clinical signs of methemoglobinemia include cyanosis of the skin, oral mucosa (as seen in Figure 1), and nail beds, chocolate colored blood, dyspnea, hypotension, altered sensorium, seizures, and death [1,2]. In an intubated patient, a high level of

observe. Cyanosis, along with a continuous $\mathrm{O}_{2}$ saturation reading $85 \%$ is heavily suggestive of methemoglobinemia. Co-oximetry demonstrating elevated methemoglobin is required for making a definitive diagnosis. Benzocaine increases levels of methemoglobin by converting ferrous $\left(\mathrm{Fe}^{2+}\right)$ to ferric $\left(\mathrm{Fe}^{3+}\right)$. The binding of oxygen to methemoglobin results in an increased affinity for oxygen to the heme sites that remain in ferrous state. This leads to an overall reduced ability of red blood cells to release oxygen to tissues and a left shifted oxygen-hemoglobin dissociation curve. The body is in a functionally anemic and hypoxemic state [3].

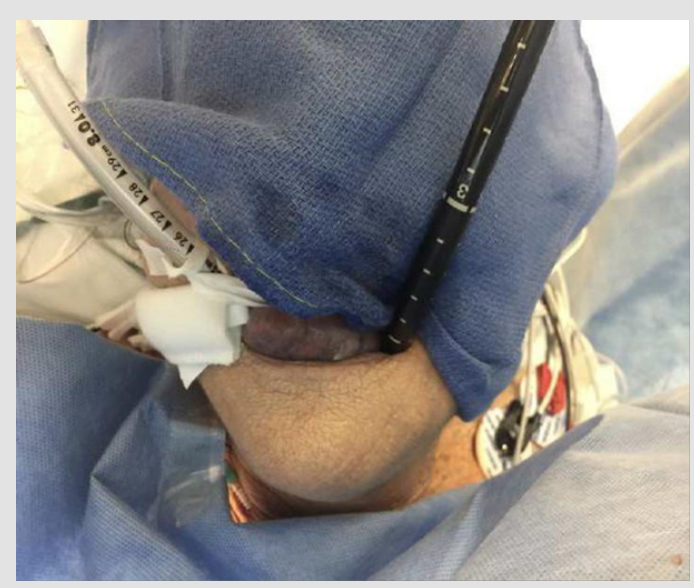

Figure 1: A Patient with a Blue Tongue, a Clinical Sign of Methemoglobinemia. 
This patient's cyanotic tongue and low $\mathrm{O}_{2} \%$ saturation prompted the use of methylene blue which acts by converting ferric back to the ferrous state $[2,3]$. We present this figure as a reminder to fellow anesthesiology practitioners of methemoglobinemia, a potentially life-threatening condition.

\section{References}

1. Birchem SK (2005) Benzocaine-Induced Methemoglobinemia During Transesophageal Echocardiography. J Am Osteopath Assoc 105(8): 381384.

ISSN: 2574-1241

DOI: 10.26717/BJSTR.2019.22.003694

Bryan A Kerner. Biomed J Sci \& Tech Res

(C) (1) This work is licensed under Creative

Submission Link: https://biomedres.us/submit-manuscript.php
2. Cortazzo JA, Lichtman AD (2014) Methemoglobinemia: A Review and Recommendations for Management. Journal of Cardiothoracic and Vascular Anesthesia 28(4): 1043-1047.

3. Robert C Darling, FJ W Roughton (1942) The effect of methemoglobin on the equilibrium between oxygen and hemoglobin. Am J Physiol 137(1): 56.

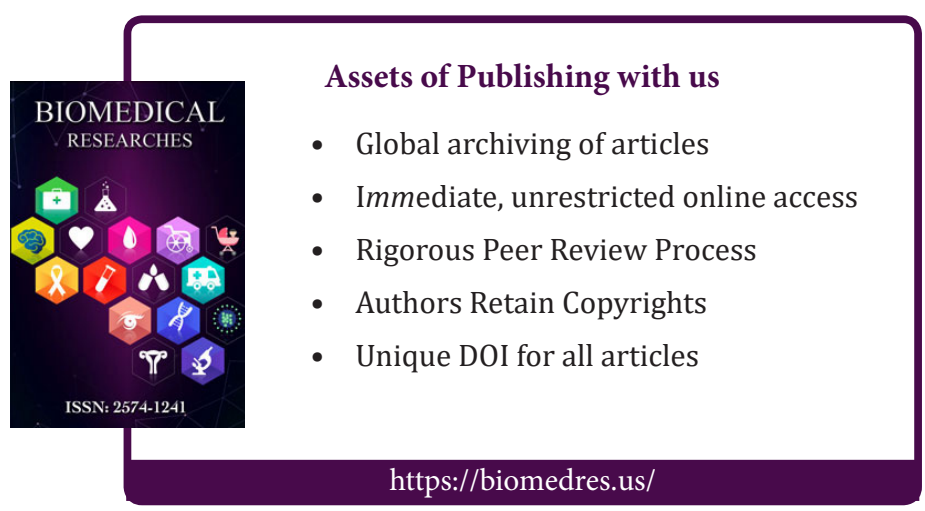

